\title{
Peningkatan kualitas hidup lansia melalui skrining risiko morbiditas dan sosialisasi penerapan pola makan sehat
}

\author{
Ardesy Melizah Kurniati ${ }^{*}$, Nur Riviati ${ }^{2}$, Syarif Husin ${ }^{1}$, Syifa Alkaf ${ }^{3}$ \\ ${ }^{1}$ Bagian Gizi, Program Studi Pendidikan Dokter, Fakultas Kedokteran, Universitas Sriwijaya \\ ${ }^{2}$ Bagian Penyakit Dalam, Program studi Pendidikan Dokter, Fakultas Kedokteran, Universitas Sriwijaya \\ ${ }^{3}$ Bagian Fisiologi, Program studi Pendidikan Dokter, Fakultas Kedokteran, Universitas Sriwijaya, \\ E-mail: ardesy.gizi@fk.unsri.ac.id
}

\begin{abstract}
Abstrak
Penuaan menyebabkan kemunduran fungsi organ tubuh secara fisiologis. Kualitas hidup dapat lebih menurun bila terdapat penyakit lain yang memperberat keadaan kesehatan orang lanjut usia (lansia). Penyakit kronik degeneratif seperti diabetes dan penyakit kardiovaskuler merupakan penyebab disabilitas pada lansia. Pola makan dan aktivitas fisik merupakan faktor yang dapat dimodifikasi untuk mencegah timbulnya morbiditas tersebut. Pada lansia yang aktif secara fisik, tetap diperlukan skrining morbiditas dan edukasi pola makan sehat untuk menunjang kesehatannya. Kegiatan pengabdian masyarakat ini terdiri dari penyuluhan tentang gizi lansia dan pemeriksaan kesehatan yang terdiri dari pemeriksaan lingkar pinggang, massa lemak tubuh, tekanan darah, kolesterol, dan gula darah sewaktu. Sebanyak lima puluh orang lansia berusia enam puluh tahun ke atas, yang terdiri dari empat puluh dua orang perempuan, dan delapan laki-laki dari komunitas lansia di Rumah Sakit Umum Pusat Dr. Mohammad Hoesin Palembang berpartisipasi pada kegiatan ini. Rerata persentase massa lemak tubuh adalah $35,01 \% \pm 9.03$. Sebanyak 6 orang $(75 \%)$ laki-laki dan 35 orang $(83.3 \%)$ perempuan memiliki ukuran lingkar pinggang melebihi normal. Terdapat 2 orang (4\%) yang memiliki kadar gula darah $\geq 200 \mathrm{~g} / \mathrm{dL}, 18$ orang (36\%) memiliki kadar kolesterol $\geq 200 \mathrm{~g} / \mathrm{dL}$, dan 12 orang (24\%) memiliki tekanan darah $\geq 150 / 90 \mathrm{mmHg}$. Sebagian besar lansia memiliki obesitas sentral dan memiliki kadar kolesterol sewaktu di atas normal. Terdapat peserta yang memiliki kadar gula darah, kolesterol, dan tekanan darah tinggi yang harus mendapatkan terapi. Peserta yang memiliki risiko penyakit disarakan melakukan pemeriksaan lanjutan. Dapat diusulkan program pendampingan diet untuk memperbaiki kondisi obesitas pada kegiatan pengabdian masyarakat selanjutnya.
\end{abstract}

Kata kunci: Skrining, Morbiditas, Pola Makan Sehat, Lansia

\begin{abstract}
Improving the quality of life of the elderly through screening for risk of morbidity and promote the healthy eating practices. Aging results physiological decline in the organ function. Quality of life can be further decreased if there are other diseases that aggravate the health condition of the elderly. Chronic diseases such as diabetes and cardiovascular disease are the causes of disability in the elderly. Diet and physical activity are factors that can prevent this morbidity. Morbidity screening and education of healthy eating patterns are still needed for elderly, who are physically active, to support their health. Community service activities consist of nutrition counseling for elderly and health checking such as examine waist circumference, body fat mass, blood pressure, cholesterol and random blood sugar test. A total of fifty elderly, aged sixty years and over, that consist of forty-two women and eight men from the elderly community at Central General Hospital. Dr. Mohammad Hoesin Palembang, was included in this activity. The mean proportion of body fat mass was $35.01 \% \pm 9.03$. As
\end{abstract}


many as $6(75 \%)$ men and $35(83.3 \%)$ women had waist circumference exceeding normal. There were 2 people $(4 \%)$ who had blood sugar levels $>200 \mathrm{~g} / \mathrm{dL}, 18$ people $(36 \%)$ with cholesterol levels $>200 \mathrm{~g} / \mathrm{dL}$, and 12 people (24\%) with blood pressure $>150 / 90 \mathrm{mmHg}$. Most of the elderly have central obesity and high cholesterol levels. There are participants who should receive therapy for having high blood sugar, cholesterol, and blood pressure. Respondents who have risk of disease are advised to carry out further examinations. A dietary assistance program could be proposed to improve obesity conditions in future community service activities.

Keywords: Screening, Morbidity, Healthy Eating Practice, Elderly

\section{PENDAHULUAN}

Lanjut usia (lansia) didefinisikan sebagai seseorang yang telah mencapai usia 60 tahun ke atas. ${ }^{1}$ Seiring waktu, terjadi kemunduran fisik secara fisiologis yang dapat menurunkan kualitas hidup lansia. Ditambah lagi, bila terdapat penyakit lain yang memperberat kondisi kesehatannya. $^{2}$ Morbiditas dapat menyebabkan disabilitas dan menimbulkan ketergantungan lansia terhadap orang lain. Disabilitas pada lansia diantaranya disebabkan oleh penyakit jantung, kencing manis, stroke, rematik, dan cedera. ${ }^{3}$ Pola makan dan aktivitas fisik merupakan faktor yang dapat dimodifikasi untuk mencegah timbulnya morbiditas pada lansia. ${ }^{4}$

Untuk menjaga dan meningkatkan kesehatan lansia di Indonesia, terdapat layanan kesehatan yang disediakan pemerintah, meliputi layanan promotif, preventif, kuratif, dan rehabilitatif sederhana. Kelompok lansia dapat memberdayakan diri untuk terus aktif dalam kegiatan komunitas, sebagai upaya meningkatkan kesehatannya. ${ }^{5}$ Komunitas Lansia di Rumah Sakit Umum Pusat Dr. Mohammad Hoesin Palembang secara rutin mengikuti kegiatan senam bersama satu kali seminggu.

Kegiatan pengabdian masyarakat ini diadakan pada komunitas lansia yang aktif secara fisik. Meskipun demikian, pemeriksaan kesehatan rutin terhadap risiko morbiditas yang umumnya terjadi pada lansia, seperti obesitas, hipertensi, hiperglikemi, dan hiperkolesterolemi tetap diperlukan sebagai upaya preventif. Selain itu, perlu diberikan edukasi tentang gizi yang tepat agar upaya menghindari morbiditas lansia dapat berjalan optimal. 


\section{TINJAUAN PUSTAKA}

Peraturan Pemerintah RI Nomor 43 tahun 2004 mendefinisikan lanjut usia (lansia) sebagai seseorang yang telah mencapai usia 60 tahun ke atas. ${ }^{1}$ Lansia dikategorikan sebagai lansia muda (60-69 tahun), lansia madya (70-79 tahun), dan lansia tua (80 tahun ke atas). Pada tahun 2019, jumlah lansia lakilaki adalah 9,10\% sedangkan perempuan $10.10 \%$ dari seluruh penduduk Indonesia. ${ }^{6}$ Angka harapan hidup yang tinggi membuat jumlah penduduk lansia yang terdata menjadi meningkat. Perkiraan angka harapan hidup penduduk Sumatera Selatan tahun 2010-2020 adalah sebesar 72,47 tahun, tidak jauh berbeda dengan penduduk Kota Palembang yang besarnya 73,81 tahun. ${ }^{7}$

Berbagai perubahan fisiologis terjadi pada lansia akibat penurunan fungsi tubuh terkait usia. Lansia kurang bisa menikmati makanan dan minuman dengan baik dikarenakan menurunnya kemampuan indera perasa dan penciuman. Hal tersebut dapat memengaruhi pemilihan makanan dan penggunaan bahan tambahan pangan di dalam masakan. Organ pencernaan dapat mengalami penurunan dan kehilangan fungsi yang mengakibatkan sistem pencernaan kurang optimal. Kekurangan dalam merasakan cita rasa makanan, jumlah gigi, dan penyakit penyerta merupakan faktor yang memengaruhi pola makan lansia. ${ }^{2}$

Setelah melewat usia 40 tahun, massa otot manusia mulai berkurang, maka seiring menuanya usia dapat terjadi kelemahan, disabilitas dan morbiditas. Berat badan laki-laki cenderung mulai menurun setelah usia 55 tahun, sedangkan pada wanita, berat badan dapat meningkat hingga usia 69 tahun dan menurun setelahnya. Meskipun demikian, tampilan yang muncul pada lansia adalah obesitas sentral. Terjadi akumulasi lemak yang dihubungkan dengan menurunnya produksi growth hormone, resistensi leptin, dan penurunan respon terhadap hormon tiroid. Massa lemak menggantikan jumlah massa otot dengan berat yang lebih rendah. ${ }^{2}$

Obesitas sentral merupakan salah satu indikator dari sindrom metabolik, selain dari adanya dislipidemia, hipertensi, dan hiperglikemi. ${ }^{8}$ Berdasarkan panduan WHO, lingkar pinggang untuk laki-laki yang normal adalah $\leq 90 \mathrm{~cm}$, sedangkan untuk perempuan adalah

$\leq 80 \mathrm{~cm} .{ }^{9}$ Penelitian pada populasi orang dewasa di Indonesia menunjukkan prevalensi 
obesitas sebesar 23,1\% dan obesitas sentral sebesar 28\%. Obesitas sentral dikaitkan dengan penyakit diabetes dan hipertensi. ${ }^{10}$

Lansia sebaiknya menjalani pemeriksaan rutin terhadap risiko morbiditas yang dimiliki. Morbiditas dapat menyebabkan disabilitas dan menimbulkan ketergantungan lansia terhadap orang lain. Rasio ketergantungan lansia kepada orang usia produktif (15-59 tahun) pada tahun 2019 terdata sebesar 15,01 yang artinya 100 penduduk usia produktif menanggung 15 lansia. ${ }^{6}$ Penyakit jantung, kencing manis, stroke, rematik, dan cedera, adalah beberapa penyebab disabilitas menurut Riset Kesehatan Dasar (Riskesdas) tahun $2018 .^{3}$

Morbiditas lansia dapat dicegah melalui asupan gizi yang tepat dan tetap aktif secara fisik. ${ }^{2}$ Untuk dapat membiasakan pola makan yang sehat, semua orang termasuk lansia, membutuhkan edukasi untuk menambah pengetahuan dalam memilih makanan dalam jumlah dan jenis yang tepat tepat sesuai kebutuhan. ${ }^{11}$

Tabel 1. Kebutuhan makronutrien pada lansia sesuai jenis kelamin

\begin{tabular}{lccc}
\hline Jenis kelamin dan usia & \multicolumn{3}{c}{ Zat Gizi Makro } \\
\cline { 2 - 4 } & Karbohidrat $(\mathrm{g})$ & Protein $(\mathrm{g})$ & Lemak $(\mathrm{g})$ \\
\hline Laki-laki & & & 65 \\
60-64 tahun & 349 & 65 & 53 \\
65-80 tahun & 309 & 62 & 42 \\
$>80$ tahun & 248 & 60 & 53 \\
Perempuan & & & 43 \\
60-64 tahun & 285 & 57 & 40 \\
65-80 tahun & 252 & 56 & \\
$>80$ tahun & 232 & 55 & \\
\hline
\end{tabular}

Pemerintah menjamin upaya peningkatan kesejahteraan sosial lansia, termasuk pelayanan kesehatan di fasilitas kesehatan milik pemerintah. Pembentukan kelompok lansia dan layanan kesehatan dari Pos Pelayanan Terpadu Lanjut Usia (Posyandu Lansia) atau Pos Pembinaan Terpadu Lanjut Usia (Posbindu Lansia) merupakan perwujudan upaya tersebut. Layanan kesehatan yang didapatkan berupa layanan promotif, preventif, kuratif, dan rehabilitatif sederhana. Selain itu, pembentukan kelompok lansia juga dapat menjadi 
wadah komunikasi hingga pemberdayaan ekonomi yang akan meningkatkan kualitas hidupnya. ${ }^{5}$

\section{METODE}

Metode kegiatan berupa pemeriksaan kesehatan dan penyuluhan. Khalayak sasaran terdiri dari laki-laki dan perempuan berusia 60 tahun ke atas, yang merupakan anggota Komunitas Lansia di Rumah Sakit Umum Pusat Dr. Mohammad Hoesin Palembang. Peserta kegiatan mengisi formulir data karakteristik dan pretest. Selanjutnya dilakukan penyuluhan tentang gizi seimbang bagi lansia, disertai dengan pembagian pamflet yang berisi materi edukasi.

Peserta menjalani pemeriksaan antropometri berupa lingkar pinggang dan pengukuran massa lemak tubuh. Setelah itu, dilanjutkan dengan pemeriksaan tekanan darah, gula darah, kolesterol sewaktu. Evaluasi dilakukan melalui penilaian keaktifan peserta berdiskusi selama penyuluhan dan juga melalui posttest.

\section{HASIL DAN PEMBAHASAN}

Kegiatan pengabdian masyarakat telah berlangsung lancar dengan lima puluh orang lansia sebagai peserta. Sebagian besar peserta adalah perempuan dan berada pada rentang usia 60-69 tahun. Rentang usia ini disebut lansia muda, merupakan jumlah terbanyak pada tiap komunitas lansia. Sisanya adalah lansia madya, dan tidak terdapat lansia tua pada komunitas ini. Meskipun proporsi lansia berdasarkan rentang usia dan jenis kelamin tidak jauh berbeda, akan tetapi jumlah perempuan yang bergabung pada komunitas lansia jauh lebih banyak. ${ }^{6}$

Setelah melakukan registrasi, peserta dipersilahkan duduk dan mengisi lembar pretest yang diberikan. Selanjutnya, penyuluhan dengan judul "Pola Hidup Sehat melalui Gizi Seimbang bagi Lansia" dimulai. Pada penyuluhan ini, dijelaskan bagaimana pedoman gizi seimbang bagi lansia, berapa kebutuhan kalori sesuai usia dan jenis kelamin, serta bagaimana cara memilih jenis makanan dan porsinya agar sesuai dengan kebutuhan tubuh. 
Beberapa peserta mengajukan pertanyaan tentang cara menggunakan tabel di dalam pamflet yang telah dibagikan.

Tabel 2. Karakteristik peserta khalayak sasaran

\begin{tabular}{lcc}
\hline Karakteristik & $\mathrm{n}$ & $\%$ \\
\hline Usia & & \\
60-69 tahun & 42 & 84 \\
$70-79$ tahun & 8 & 16 \\
Jenis kelamin & & \\
$\quad$ Laki-laki & 8 & 16 \\
$\quad$ Perempuan & 42 & 84 \\
\hline
\end{tabular}
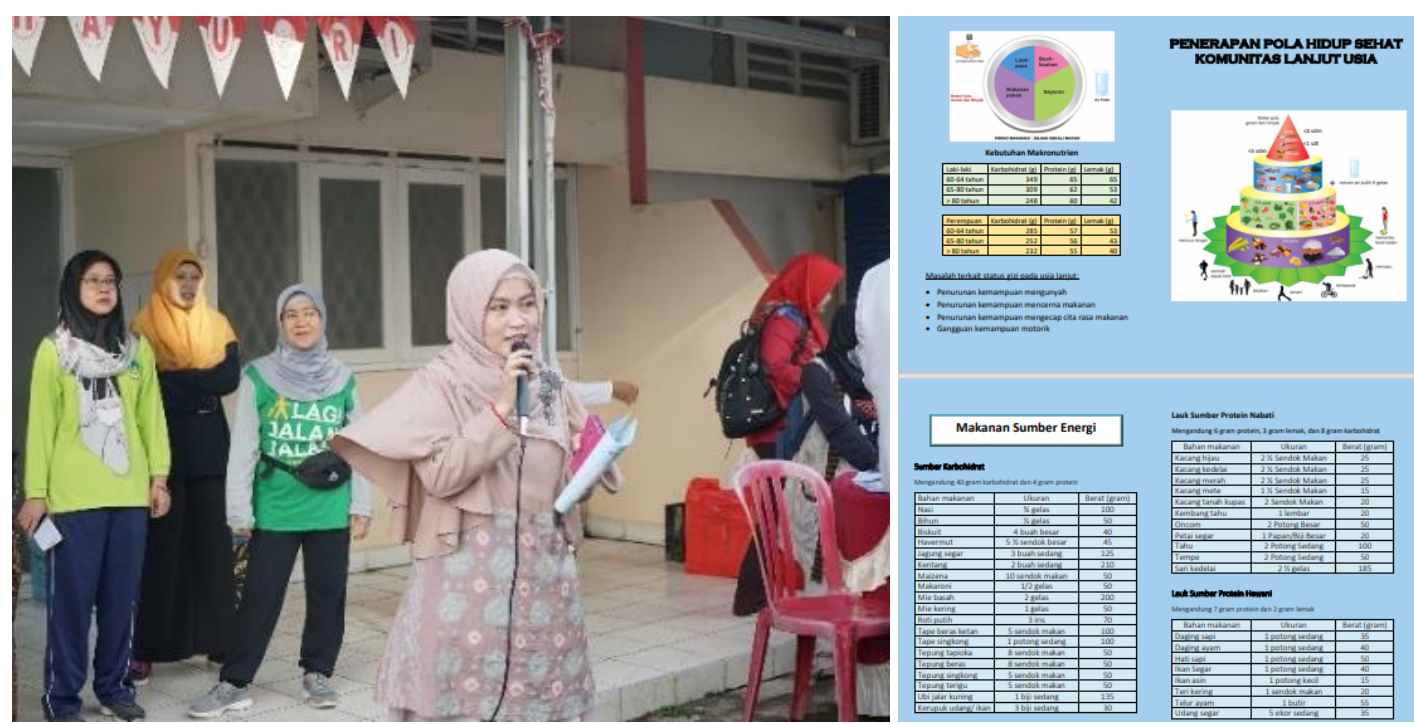

Gambar 1. Penyuluhan Gizi seimbang (kiri) dan pamflet edukasi (kanan)

Peserta kemudian dipanggil sesuai giliran menuju pos khusus untuk menjalani pencatatan identitas, pemeriksaan antropometri berupa pengukuran lingkar pinggang dan lingkar lengan, serta pemeriksaan komposisi tubuh yaitu massa lemak tubuh. Peserta selanjutnya menjalani pemeriksaan tekanan darah, kadar gula darah, dan kolesterol sewaktu.

Bila dibandingkan dengan rerata massa lemak tubuh lansia tanpa penyakit kronik pada populasi lain $(31,5 \%+8,5)$, rerata persentase massa lemak tubuh pada peserta kegiatan 
ini lebih tinggi. ${ }^{12}$ Berdasarkan pemeriksaan antropometri, sebanyak 6 orang laki-laki (75\%) memiliki lingkar pinggang berlebih, sedangkan perempuan sebanyak 35 orang (83,3\%). Lingkar pinggang melebihi standar ini menggambarkan obesitas sentral, dan berkorelasi dengan indeks massa tubuh lebih dari $30 \mathrm{~kg} / \mathrm{m}^{2}$, sehingga status gizi masuk dalam kategori obesitas. ${ }^{13}$

Tabel 3. Hasil pemeriksaan kesehatan

\begin{tabular}{lcc}
\hline Hasil pemeriksaan & Mean & SD \\
\hline $\begin{array}{l}\text { Antropometri } \\
\quad \text { Lingkar pinggang (cm) } \\
\text { Komposisi Tubuh } \\
\quad \text { Massa lemak (\%) }\end{array}$ & 88.78 & 10.24 \\
Pemeriksaan darah & 35.01 & \\
$\quad$ GDS (g/dL) & 114.62 & 9.03 \\
$\quad$ Kolesterol (g/dL) & 193.89 & 35.60 \\
Tekanan darah & & 44.65 \\
$\quad$ Sistolik & 135.67 & \\
$\quad$ Diastolik & 77.83 & 29.49 \\
\hline
\end{tabular}
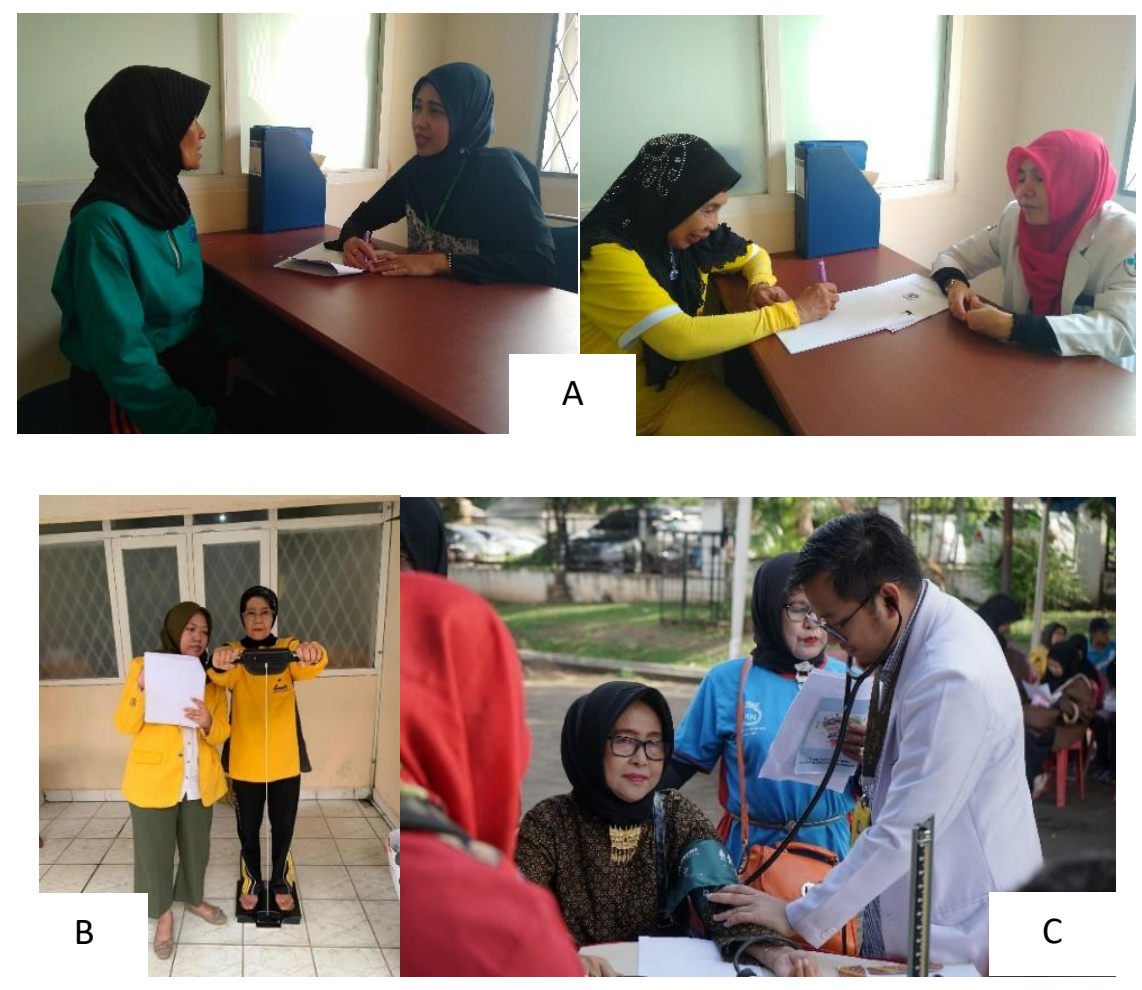

Gambar 2. Pengisian formulir (A), pemeriksaan massa lemak tubuh (B), pemeriksaan tekanan $\operatorname{darah}(\mathrm{C})$ 
Berdasarkan panduan Joint National Commitee (JNC) 8, terapi farmakologis untuk menurunkan tekanan darah pasien di atas usia 60 tahun dimulai bila nilai sistolik $\geq 150$ mmHg dan diastolik $\geq 90 \mathrm{mmHg} \cdot{ }^{14}$ Hasil pemeriksaan peserta menunjukkan rerata yang belum mencapai batas harus diterapi. Namun, terdapat 12 orang (24\%) lansia dengan tekanan darah sistolik dan diastolik melebih batas.

Pada pemeriksaan gula darah sewaktu, hanya terdapat 2 orang peserta (4\%) yang memiliki kadar gula darah lebih dari $200 \mathrm{~g} / \mathrm{dL}$. Sebanyak 18 peserta memiliki kadar kolesterol total lebih dari $200 \mathrm{~g} / \mathrm{dL}$ (36\%). Seluruh peserta yang memiliki risiko penyakit hipertensi, diabetes melitus, dan dislipidemia pada kegiatan ini disarankan untuk melakukan pemeriksaan lanjutan ke fasilitas kesehatan terdekat.

Setelah semua peserta selesai melakukan semua pemeriksaan, peserta diarahkan menuju meja akhir data untuk mengisi posttest sebagai bentuk evaluasi terhadap peningkatan kemampuan peserta setelah mengikuti kegiatan ini. Terdapat peningkatan pengetahuan yang ditunjukkan dengan nilai sempurna untuk semua peserta.

\section{SIMPULAN}

Sebagian besar lansia memiliki obesitas sentral. Terdapat peserta yang memiliki kadar gula darah, kadar kolesterol dan tekanan darah tinggi yang harus mendapatkan terapi. Peserta yang memiliki risiko penyakit sebaiknya melakukan pemeriksaan lanjutan. Untuk kegiatan selanjutnya, dapat dilakukan pendampingan diet dalam rangka memperbaiki status gizi bagi yang mengalami obesitas.

\section{Ucapan Terima Kasih}

Terima kasih kepada Ibu Cholijah selaku koordinator komunitas lansia, Direktur RSMH, dan semua pihak yang membantu baik dari FK Unsri maupun RSMH. Kegiatan ini didanai oleh Hibah Pengabdian Masyarakat Fakultas Kedokteran Universitas Sriwijaya Nomor: 109/ 017/ UN9.1.4/ PLP-PPM/PL/X/2019 tanggal: 1 Oktober 2019. 


\section{Referensi}

1. Peraturan Pemerintah Republik Indonesia nomor 43 tahun 2004 tentang pelaksanaan upaya peningkatan kesejahteraan sosial lanjut usia. Bagian Peraturan Perundangundangan Biro Hukum \& Humas Badan Pengawas Keuangan dan Pembangunan Indonesia; 2004 p. 1-17.

2. Amarya S, Singh K, Sabharwal M. Ageing process and physiological changes. In: Gerontology. InTech; 2018 [cited 2019 Sep 10]. p. 3-24.

3. Hasil utama Riskesdas 2018 [Internet]. Badan Penelitian dan Pengembangan Kesehatan Kementerian Kesehatan RI; 2018 [cited 2019 Sep 10].

4. Machón M, Mateo-Abad M, Vrotsou K, Zupiria X, Güell C, Rico L, et al. Dietary patterns and their relationship with frailty in functionally independent older adults. Nutrients. 2018;10(4).

5. Peraturan Menteri Kesehatan Republik Indonesia no 25 tahun 2016 tentang rencana aksi nasional kesehatan lanjut usia tahun 2016-2019. Kementerian Kesehatan RI; 2016 p. 1-96.

6. Maylasari I, Rochmawati Y, Wilson H, Nugroho SW, Sulistyowati NP, Dewi FWR. Statistik penduduk lanjut usia 2019 [Internet]. Badan Pusat Statistik; 2019 [cited 2019 Sep 11].

7. Profil kesehatan tahun 2018 [Internet]. Dinas Kesehatan Kota Palembang; 2018 [cited 2019 Sep 10].

8. Rochlani Y, Pothineni NV, Kovelamudi S, Mehta JL. Metabolic syndrome: Pathophysiology, management, and modulation by natural compounds. Ther Adv Cardiovasc Dis. 2017;11(8): 215-25.

9. Waist circumference and waist-hip ratio [Internet]. World Health Organization; 2018 [cited 2019 Sep 10].

10. Harbuwono DS, Pramono LA, Yunir E, Subekti I. Obesity and central obesity in indonesia: Evidence from a national health survey. Med J Indones. 2018;27(2): 53-9.

11. Peraturan Menteri Kesehatan Republik Indonesia nomor 41 tahun 2014 tentang pedoman gizi seimbang. Indonesia: Kementerian Kesehatan RI; 2014 p. 1-96.

12. Kim S, Leng XI, Kritchevsky SB. Body composition and physical function in older adults with various comorbidities. Innov Aging. 2017;1(1): 1-9.

13. National Health and Nutrition Examination Survey (NHANES). Anthropometry procedures manual. CDC; 2007. $102 \mathrm{p}$.

14. Muhadi. JNC 8: Evidence-based guideline penanganan pasien hipertensi dewasa. Cermin Dunia Kedokt. 2016;43(1): 54-9. 